\title{
Long-term application of fertilizers on chemical and biological properties of an Alfisol
}

\author{
R. C. Gowda, P. Veeranagappa*, B. Gayathri, D. C. Hanumanthappa and Muneshwar \\ Singh
}

Department of Soil Science and Agricultural Chemistry, University of Agricultural Sciences, Gandhi Krishi Vignana Kendra, Bangalore (Karnataka), INDIA

*Corresponding author. E-mail: veera346@gmail.com

Received: December 6, 2016; Revised received: May 10, 2017; Accepted: September 12, 2017

\begin{abstract}
A long term fertilizer experiment (30 years) at Bengaluru had been started during 1986 with eleven treatments and four replications in an Alfisol on finger millet (Elusine coracana)-maize (Zea mays) cropping sequence. The results of the ongoing experiment after 27 cycles of finger millet and maize on changes in soil chemical properties revealed that application of inorganics alone resulted in impaired soil fertility status (soil pH, organic carbon content and available nutrients in soil were decreased) over balanced fertilizer application. There was a decline in soil reaction over the initial status and the maximum decrease was observed in $100 \% \mathrm{NP}(-1.46), 100 \% \mathrm{~N}(-1.20)$ and other treatments. Application of $100 \%$ NPK+FYM+lime maintained the soil pH (6.2) compared to all the other treatments. Organic carbon content of soil in all the treatments was higher $\left(6.46 \mathrm{~g} \mathrm{~kg}^{-1}\right)$ compared to the initial status; however, maximum increase in organic carbon content was registered on application of NPK+FYM. Application of $10 \mathrm{t} \mathrm{ha}^{-1}$ along with recommended dose of fertilizers and lime was found promising in term of sustaining crop and soil productivity.
\end{abstract}

Keywords: Alfisol, Enzyme activity, Finger millet, Fertilizers, Maize

\section{INTRODUCTION}

In the context of soil fertility management, long-term fertilizer experiments (LTFEs) are valuable assets for determining yield trends, changes in nutrient dynamics and balances, predicting soil carrying capacity, assessing soil quality and system sustainability. Soil fertility, one of the important determinants of agricultural productivity, is generally thought to be supplemented through the application of nutrients mainly through inorganic fertilizers. Application of inorganic fertilizers alone caused the soil acidity, nutrients imbalance in soil over the years. The main reasons of unfavourable changes in soil and other components of agroecosystems are a lack or low organic fertilization, imbalanced mineral fertilization, high doses of nitrogen, skipping liming, lower fertilizer doses as compared crop needs. As a result, the following effects are observed: a decrease of organic carbon content, strong acidification, changes in total and available nutrients contents, deterioration in physical and biological soil properties Jaskulska et al. (2014).The declining crop productivity has generally been attributed to the declining soil chemical fertility. Chemical fertilizers with instant ability to restore depleted nutrients in necessary quantities and these fertilizers in combination with organics and amendments are recognized as a key component of sustainable soil fertility management.
Inorganic fertilizers, especially $\mathrm{N}, \mathrm{P}$ and $\mathrm{K}$ not only serve to maintain or improve crop yields, but their application directly or indirectly causes changes in chemical, physical and biological properties of the soil (Zhong and Cai, 2007) Application of either alone or dual fertilizers resulted in soil nutrients imbalance, soil acididy and poor crop performance. These changes, in the long-term, are believed to have significant influences on the quality and productive capacity of the soil (Acton and Gregorich, 1995). Effects of management practices on soil quality and productivity are best evaluated using long-term experiments. A long term fertilizer experiment at Bangalore, India was started in 1986-87 with finger millet - maize cropping sequence on a typic kandicustalfs. The objective of the study was to monitor the changes in soil properties as a result of continuous manuring and cropping with respect to the chemical and microbiological characteristics of the soil in relation to its productivity.

Long-term experiments point to a complex of direct and indirect changes in physicochemical and biological soil properties affected by the application of organic and mineral fertilizers or no fertilizers at all. Fertilization affects soil properties essential for its agricultural quality and ecological balance: the content and transformations of organic carbon (Kubat et al., 2006), acidification and soil reaction (Debreczeni and Kis- 
manyoky, 2005), nutrients contents as well as their availability to plants (Madaras and Lipavsky, 2009). Soil microbial diversity is one of the most important microbial parameters in soil. It has been demonstrated that soil microbial diversity is affected by anthropogenic disturbance (Fox and MacDonald, 2003).

\section{MATERIALS AND METHODS}

The experimental site is located at an altitude of 930 meters above MSL, latitude of $13^{\circ}$ north, longitude of $77^{\prime \prime} 3^{\prime}$ east. The annual rainfall occurs from April to November with the average rain fall of $920.4 \mathrm{~mm}$. During the cropping period the weather conditions prevailed were normal except for variations in rainfall pattern.There are eleven fixed treatments established in permanently laid out plots in randomized block design with four replications on finger millet - maize cropping sequence. Neither the treatments nor the management practices in respect of fertilizers doses, irrigation and plant protection measures have changed over the years. The treatments details are as under:

$\mathrm{T}_{1}: 50 \% \mathrm{NPK}$

$\mathrm{T}_{2}: 100 \% \mathrm{NPK}$

$\mathrm{T}_{3}: 150 \% \mathrm{NPK}$

$\mathrm{T}_{4}: 100 \% \mathrm{NPK}+\mathrm{HW}$

$\mathrm{T}_{5}: 100 \% \mathrm{NPK}+$ Lime

$\mathrm{T}_{6}: 100 \% \mathrm{NP}$

$\mathrm{T}_{7}: 100 \% \mathrm{~N}$

$\mathrm{T}_{8}: 100 \% \mathrm{NPK}+\mathrm{FYM}$

$\mathrm{T}_{9}: 100 \% \mathrm{NPK}(\mathrm{S}$-free $)$

$\mathrm{T}_{10}: 100 \% \mathrm{NPK}+\mathrm{FYM}+$ lime

$\mathrm{T}_{11}$ :Control

Lime, as per lime requirement test is applied only when found necessary, during the kharif season. Well decomposed Farmyard manure (FYM) at the rate of 15 $\mathrm{t} \mathrm{ha}^{-1}$ on dry weight basis is incorporated into the soil 10-15 days before sowing of the kharif crop. Half the dose of the nitrogen, full dose of $\mathrm{P}$ and $\mathrm{K}$ applied as basal and remaining half of nitrogen dose is applied after 25 to 30 days of sowing / transplanting of crops as top dress. Diammonium phosphate (DAP) is used as a source of $\mathrm{P}$ and $\mathrm{N}$ along with urea and muriate of potash (MoP) in 100\% NPK (-S). For all the treatments (except $100 \%$ NPK -S), urea, single super phosphate are used assources of NPK fertilizers. Neither any chemical fertilizer nor any organic manure is used in absolute Control (No NPK) treatment.

Soil reaction, organic carbon, available $\mathrm{N}, \mathrm{P}, \mathrm{K}$ and secondary nutrients status of soil were estimated every year after completion of each cropping sequence. Soil quality parameters were analysedin the site during 2009 after the harvest of maize. The available $\mathrm{N}$ (alkaline permanganate method, Subbiah and Asija, 1956); Available $\mathrm{P}$ was extracted with $\mathrm{NH}_{4} \mathrm{~F}-\mathrm{HCl}$ solution (Bray and Kurtz, 1945), available potassium was extracted from $1 \underline{\mathrm{N}} \mathrm{NH}_{4} \mathrm{OAC}-\mathrm{K}$ (Hanway and Heidel, 1952) and soil organic $\mathrm{C}$ concentration (Walkley and
Black, 1934) were alsoestimated from soil samples. The soil is typic kandicustalfs with sandy clay loam texture. Initially the soil reaction was acidic (6.17), low in organic carbon content $\left(4.60 \mathrm{~g} \mathrm{~kg}^{-1}\right)$ and available NPK contents of the soil are $256.7 \mathrm{~kg} \mathrm{ha}^{-1}, 34.30$ $\mathrm{kg} \mathrm{ha}^{-1}$ and $123.10 \mathrm{~kg} \mathrm{ha}^{-1}$ respectively.

Microbial biomass: Microbial biomass was estimated using the $\mathrm{CHCl}_{3}$ fumigation-extraction method (Vance et al., 1987). Samples of moist soil (10 g) were used, and $\mathrm{K}_{2} \mathrm{SO}_{4}$-extractable $\mathrm{C}$ was determined using dichromate digestion. Microbial biomass $\mathrm{N}$ was calculated as a difference in $\mathrm{N}$ content in fumigated and non-fumigated sample $\left(\mathrm{E}_{\mathrm{N}}\right)$ using $\mathrm{k}_{\mathrm{EN}}$ coefficient (microbial biomass $\mathrm{N}=$ $\mathrm{E}_{\mathrm{N}}: \mathrm{k}_{\mathrm{EN}}$ ). The value of $\mathrm{k}_{\mathrm{EN}}=0.54$ was used to calculate microbial biomass N (Jenkinson, 1988).

Dehydrogenase activity: Dehydrogenase activity was determined using the method of Casida et al. (1964). Soil samples ( $3 \mathrm{~g}$ ) were mixed with $0.04 \mathrm{~g} \mathrm{CaCO}_{3}, 1$ $\mathrm{ml}$ of $3 \%$ aqueous triphenyl-tetrazolium chloride (TTC) solution and $2.5 \mathrm{ml}$ of distilled water in test tubes. The tubes were sealed, shaken and incubated at $37^{\circ} \mathrm{C}$ for $24 \mathrm{hr}$. TTC-formazan was extracted from the soil suspension with $\mathrm{CH}_{3} \mathrm{OH}$, filtered, and made up to $50 \mathrm{ml}$ with additional $\mathrm{CH}_{3} \mathrm{OH}$. The absorbance at 485 $\mathrm{nm}$ of the extracts was measured by spectrophotometer (Shimadzu UV-1800) using $\mathrm{CH}_{3} \mathrm{OH}$ as a blank.

Acid phosphatase activity: Acid phosphatase activity was assayed using $1 \mathrm{~g}$ of soil (wet equivalent), $4 \mathrm{ml}$ of $0.1 \mathrm{M}$ modified universal buffer ( $\mathrm{pH} 6.5$ ), and $1 \mathrm{ml}$ of $25 \mathrm{~m} \mathrm{M}$ p-nitrophenyl phosphate. After incubation for $1 \mathrm{hr}$ at $37 \pm 1^{\circ} \mathrm{C}$, the enzyme reaction was stopped by adding $4 \mathrm{ml}$ of $0.5 \mathrm{M} \mathrm{NaOH}$ and $1 \mathrm{ml}$ of $0.5 \mathrm{M} \mathrm{CaCl}_{2}$ to prevent dispersion of humic substances. After centrifugation at $4000 \mathrm{rpm}$ for $10 \mathrm{~min}$, the absorbance was measured in the supernatant at $400 \mathrm{~nm}$; enzyme activity was expressed as $\mu \mathrm{g} / \mathrm{PNP} / \mathrm{g} / 24 \mathrm{hr}$.

Microbial population: Ten gram of pooled soil was mixed in $90 \mathrm{ml}$ sterilized blank to give $10^{-1}$ dilution subsequent dilutions to $10^{-6}$ were made by transferring serially $1 \mathrm{ml}$ of the dilution to $9 \mathrm{ml}$ of sterilized blank. The populations of bacteria, fungi, and actinomycetes were estimated by transferring $1 \mathrm{ml}$ of $10^{-6}$ and $10^{-3}$ and $10^{-4}$ dilutions respectively to a sterile petridish and approximately $20 \mathrm{ml}$ of media viz., soil extract agar for soil bacteria, Martin's rose Bengal agar for fungi and Kuster's agar for actinomycetes respectively was poured into plates the plates were rotated twice in clockwise and anticlockwise direction for uniform distribution of the inoculums. After solidification of media, plates were kept for incubation in an inverted position at $30^{\circ} \mathrm{C}$ for a week time and emerged colonies were counted (Tate, 1995).

In order to compare the treatments, the data was pooled over the years and an analysis of variance (ANOVA) was performed following standard procedures for randomized block design (Gomez and Gomez, 1984). The F-test was used to test significant 
differences between treatment means. The significant differences between treatments were compared with the critical difference at $5 \%$ level of probability.

\section{RESULTS AND DISCUSSION}

The results of the experiment revealed that there was a decline in soil reaction over the initial status and the maximum decrease was observed in $100 \% \mathrm{NP}(-1.46)$, $100 \% \mathrm{~N}(-1.20)$ and other treatmentswithout application of lime/organics (Table 1). Application of $100 \%$ $\mathrm{NPK}+\mathrm{FYM}+$ lime $\left(\mathrm{T}_{10}\right)$ maintained the soil $\mathrm{pH}$ upto 6.21 compared to all the other treatmentswhen compared with the initial status. Organic carbon content of soil in all the treatments was higher compared to the initial status, however, maximum increase in organic carbon content was registered on application of NPK+FYM. The organic carbon content varied form 4.82 to $6.26 \mathrm{~g} \mathrm{~kg}^{-1}$ in the treatments which was slightly higher as compared to the original value due to its addition through roots or farm yard manure in $T_{8}$ and $T_{10}$ treatments. Higher soil organic carbon content was noted on combined application of FYM and mineral fertilizers (Bhattacharyya et al., 2010). Soil organic C content was improved from the start of the experiment in the unfertilized plots due to $\mathrm{C}$ addition through the roots and crop residues, higher humification rate constant, and lower decay rate (Kundu et al., 2002 and Enke Liu et al., 2010).

Among the major nutrients status in soil, available nitrogen content of soil has decreased in all the treatments except in $100 \% \mathrm{NPK}$ +hand weeding and $150 \%$ NPK, the magnitude of nitrogen loss was higher in absolute control where there was no application of fertilizers. This indicated that the loss of nitrogen is higher over its application due to crop removal and other losses. Application of $100 \%$ NPK + FYM and super optimal dose ( $150 \%$ NPK) recorded a significant build-up of available $\mathrm{P}$ followed by all other treatments except $100 \% \mathrm{~N}$ and control.The long-term con-

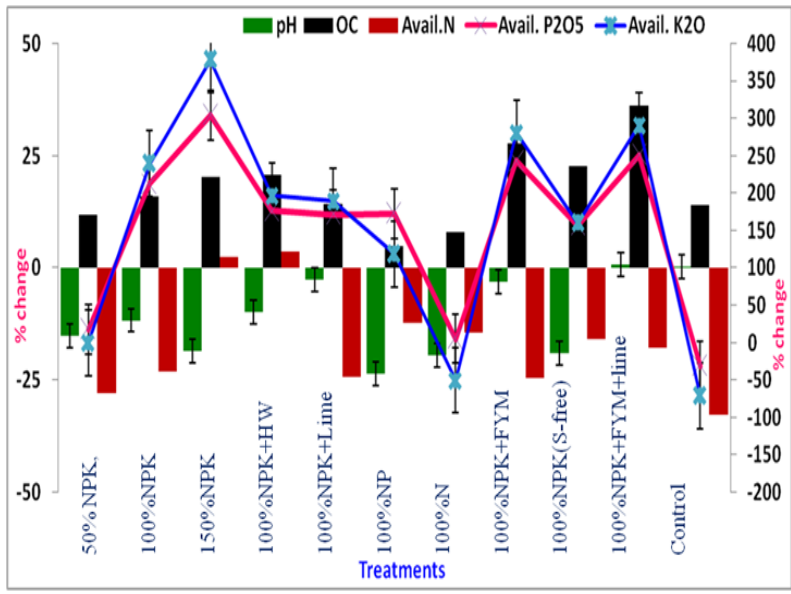

Fig. 1. Changes in soil properties over the initial value after $27^{\text {th }}$ cycle of Finger millet- maize croppingsequence.

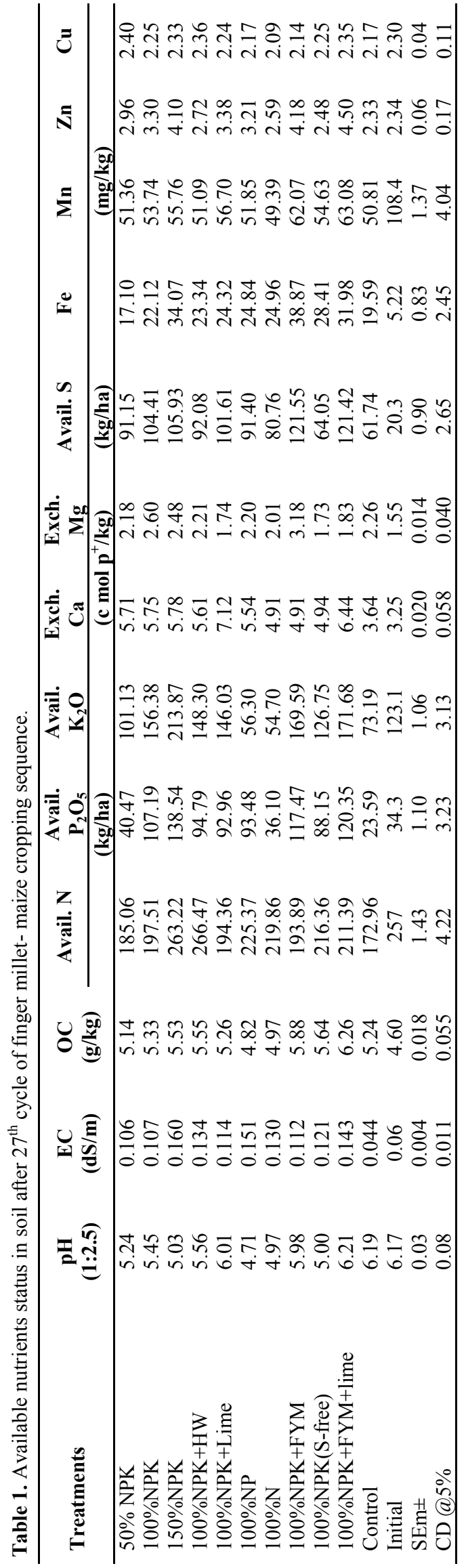




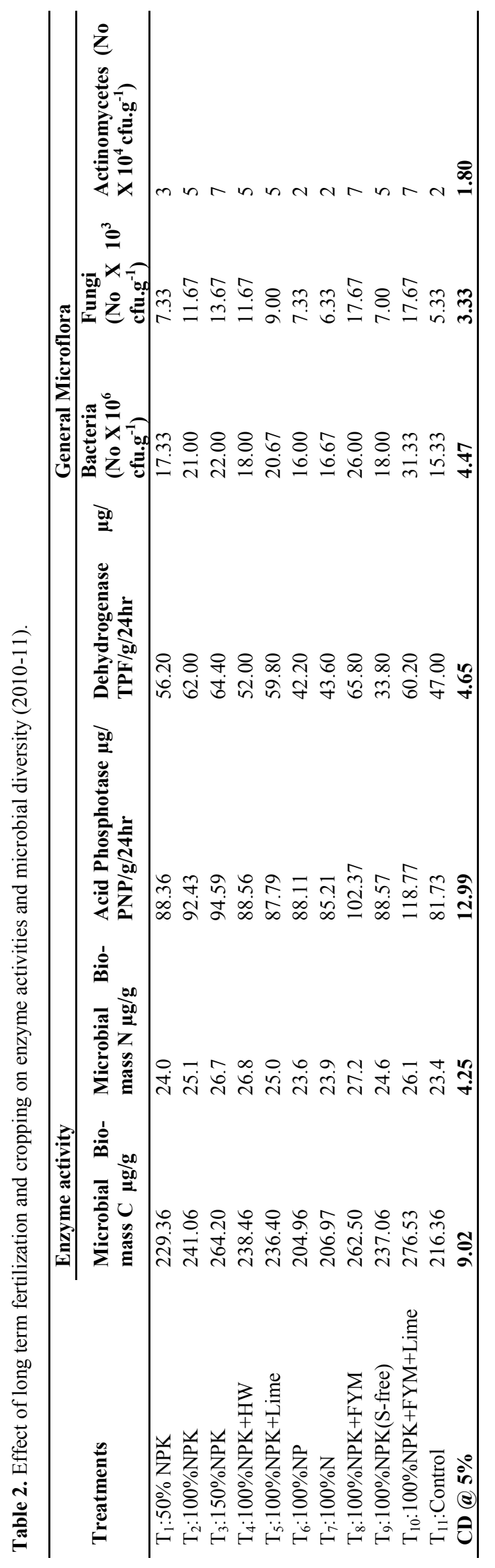

tinuous inorganic fertilizer application, had a significant contribution to soil $\mathrm{P}$ availability and its build up in soil due to soil fixation (Wang et al., 2010) Maximum potassium buildup was recorded on application of $150 \%$ NPK $\left(90.77 \mathrm{~kg} \mathrm{ha}^{-1}\right)$ followed by $100 \%$ $\mathrm{NPK}+\mathrm{FYM}+$ lime and other treatments, the available potassium content in soil was depleted in treatments where $\mathrm{K}$ was not applied $\left(\mathrm{T}_{6}, \mathrm{~T}_{7}\right.$ and $\left.\mathrm{T}_{11}\right)$ and also on application of $50 \% \operatorname{NPK}\left(\mathrm{T}_{1}\right)$. The depletion of major nutrients status in soil was due to higher crop removal, imbalanced nutrition or no application of fertilizers. Regular application of lime and FYM resulted in build of phosphorus and potassium. The present results corroborated the findings of Jaskulska et al. (2014).

The secondary nutrients statues in soil found to increase in all the treatments over the initial values, however application of balanced fertilizers resulted in higher buildup in soil compared to absolute control and inorganics alone. The increase in these nutrients contents is due to application of chemical fertilizers, farm yard manure and lime which contained appreciabe amounts of these elements. Among the micronutrients in soil, Mn content was depleted to about $50 \%$ over the initial status and $\mathrm{Cu}$ content was also reduced in all the treatments over the years due to crop uptake and soil nutrients interaction (Fig. 1). Iron content of soil showed increasing trend over the initial status in all the treatments and the $\mathrm{Zn}$ content followed the similar trend.

Phosphatase and dehydrogenase activities were related to organic matter build-up (Table 2). The greater activities of phosphatase, in the FYM treated soils may be due to enhanced microbial activity and diversity of phosphate solubilizing bacteria due to manure input over the years. The dehydrogenase activity in this study could not be related to soil organic $\mathrm{C}$ or to microbial biomass C. Dehydrogenase activity, as a measure of soil microbial activity, is strongly influenced by the presence of nitrate, which serves as an alternative electron acceptor resulting in low activities (Sneh Goyal et al., 1999). Dehydrogenase was highly sensitive to the inhibitory effects associated with large fertilizer additions. The effects of fertilization on dehydrogenase activity may be direct, related for example to changes in the availability of nutrients or heavy metals present in the fertilizers as contaminants (Simek et al., 1999).

Use of FYM alone or in combination with chemical fertilizers led to higher numbers of microbes and enhanced microbial respiration than use of chemical fertilizers alone. Farm manure is rich in organic matter and an important source of nutrients for plants and microorganism in soil, its incorporation into soil promotes microbiological activities and improves chemical fertilizer use efficiency. Bacteria were more numerous $(1 \times$ $10^{5} \mathrm{cfu}$ (colonies forming units) g dry wt. soil ${ }^{-1}$ ) than fungi $\left(1 \times 10^{3} \mathrm{cfu} \mathrm{g}\right.$ dry wt. soil $\left.{ }^{-1}\right)$ which may lead to more soil organic matter (SOM) mineralization and 
less SOM retention in this cropping system (Table 2). It is evident from the study that in treatments receiving farm yard manure microbial population were higher compared to the no FYM applied plots and this may be attributed to more availability of carbon (Belay et al. (2002).

\section{Conclusion}

Application of chemical fertilizers alone resulted in soil acidification upto 1.46 units reduction over the original value wherein application of $100 \%$ $\mathrm{NPK}+\mathrm{FYM}+$ lime maintained the soil pH (6.2) compared to all the other treatments. Application of farm manure at $10 \mathrm{t} \mathrm{ha}^{-1}$ along with recommended dose of fertilizers and lime found promising in term of sustaining crop and soil productivity. Phosphorus build up was observed over the years on application of fertilizers, secondary nutrients in soil were not decreased due to their application through the fertilizers, manure and lime over the years. Balanced nutrition (100\% $\mathrm{NPK}+\mathrm{FYM}+$ lime) ensured greater microbial activities and higher microbial population suggesting their vital role as a part of sustainable agriculture. Application of balanced fertilizers along with oganic manure and amendments could result in maintaining and sustaining the soil fertility and productivity over the years.

\section{REFERENCES}

Acton,D.F. and Gregorich, L.J. (1995). The Health of Our Soils: Toward Sustainable Agriculture in Canada. Agric. Agri-Food Canada, CDR Unit, Ottawa

Belay, A.,Claassens,A.S. and Wehner, F.C. (2002). Effect of direct nitrogen and potassium and residual phosphorus fertilizers on soil chemical properties, microbial components and maize yield under long-term crop rotation. Biol. Fertil. Soils. 35: 420-42

Bhattacharyya, R., Prakash, V., Kundu, S., Srivastva, A.K., Gupta.H.S. and Mitra, S. (2010). Long term effects of fertilization on carbon and nitrogen sequestration and aggregate associated carbon and nitrogen in the Indian sub-Himalayas. Nutr. Cycl. Agroecosyst. $86: 1-16$

Bray, R.H. and Kurtz, L.T. (1945). Determination of total, organic, and available forms of phosphorus in soils. Soil Sci., 59: 39-45

Casida, L.E.JR., Klein, D.A. and Santaro, T. (1964). Soil dehydrogenase activity. Soil Sci., 96: 371-376

Debreczeni, K. and T. Kismányoky, (2005). Acidification of soils in long-term field experiments. Commun. Soil Sci. Pl. Anal., 36: 321-329

Fox, C.A. and MacDonald, K.B. (2003).Challenges related to soil biodiversity research in agro-ecosystems - issues within the context of scale of observation. Can. J. Soil Sci., 83: 231-244

Gomez, K.A. and Gomez, A.A. (1984). Statistical procedures for agricultural research, IRRI, Willey -Inter Science Pub. Newyork, USA
Hanway, J.J. and Heidel, H. (1952). Soil analyses methods as used in Iowa State College Soil Testing Laboratory. Iowa Agriculture, 57: 1-31

Jaskulska, I., Jaskulski,D. and Kobierski, M. (2014). Effect of liming on the change of some agrochemical soil properties in a long-term fertilization experiment. Plant Soil Environ., 60(4): 146-150

Jenkinson, D.S. (1988). The determination of microbial biomass carbon and nitrogen in soil. In: Wilson J.R. (Ed.): Advances in Nitrogen Cycling in Agricultural Ecosystems. CAB International, Wallingford: 368-386

Enke Liu, Changrong Yan, Xurong Mei, Wenqing He, So Hwat Bing, Linping Ding, Qin Liu, Shuang Liu, Tinglu Fan (2010). Long-term effect of chemical fertilizer, straw, and manure on soil chemical and biological properties in northwest China. Geoderma, 158(3-4):173-180

Kubat, J., Cerhanova, D., Novakova,J. and Lipavsky, J. (2006). Total organic carbon and its composition in long-term field experiments in the Czech Republic. Archives of Agronomy and Soil Science, 52:495-505

Kundu, S., Prakash, V., Ghosh, B.N., Singh, R.D., Srivastva, A.K. (2002). Quantitative relationship between annual carbon inputs and soil organic carbon build-up in soybean (Glycine max)-wheat (Triticum aestivum) cropping sequence. $2^{\text {nd }}$ Intern. Agron. Congress, Nov. 26 30, New Delhi, India, pp. 108-110

Madaras, M. and Lipavsky, J. (2009). Interannual dynamics of available potassium in a long-term fertilization experiment. Plant Soil Environ., 55: 334-343

Simek, M., Hopkins, D.W., Kalcík, J., Picek, T., Santruckova, H., Stana,J. andTravník, K. (1999). Biological and chemical properties of arable soils affected by longterm organic and inorganic fertilizer applications. Biol. Fertil. Soils, 29: 300-308

Sneh Goyal, Chander, K., Mundra,M. C. and Kapoor, K.K. (1999).Influence of inorganic fertilizers and organic amendments on soil organic matter and soil microbial properties under tropical conditions. Biol. Fertil. Soils, 29: 196-200

Subbiah, B.V. and Asija, G.L. (1956). A rapid procedure for the estimation of available nitrogen in soils. Curr. Sci., 25: $259-260$

Tate, R. L. (1995). Soil Microbiology. John Wiley and sons, New York

Vance E.D., Brookes,P.S. and Jenkinson, D.S. (1987). An extraction method for measuring soil microbial biomass C. Soil Biol. Biochem., 19: 703-707

Walkley, A.J. and Black, C.A. (1934). An examination of the method for determining soil organic matter and a proposed modification of the chromic acid titration method. Soil Sci., 37: 29-38

Wang, J., Liu, W. Z., Mu, H. F. and Dang, T. H. (2010). Inorganic phosphorus fractions and phosphorus availability in a calcareous soil receiving 21-year superphosphate application. Pedosphere. 20(3): 304-310

Zhong, W.H. and Cai, Z.C. (2007). Long-term effects of inorganic fertilizers on microbial biomass and community functional diversity in a paddy soil derived from quaternary red clay. App. Soil Ecol., 36: 84 - 91 